\title{
Clinical and epidemiological profile of sickle cell anemia in children: an integrative review
}

\author{
Perfil clínico e epidemiológico da anemia falciforme em crianças: uma revisão integrativa \\ Perfil clínico y epidemiológico de la anemia falciforme en niños: una revisión integradora \\ Giselle Coelho Carvalho ${ }^{1}$, Joabe Lima Araújo ${ }^{2 *}$, Gardênia Taveira Santos ${ }^{3}$, Romeu Alves Vieira ${ }^{4}$, \\ Camila Cristina Bastos Silva Raposo Ramos ${ }^{1}$.
}

\begin{abstract}
Objective: The aim of this study is to analyze the clinical epidemiological profile of children with sickle cell anemia published in the literature over the last ten years. Methods: It is an integrative review. To search the articles, the Virtual Health Library (VHL) was used, and the articles from the database of the Scientific and Technical Literature of Latin America and the Caribbean (LILACS) of the Medical Literature Analysis and Retrieval System Online (MEDLINE) database were selected, data from the Scientific Electronic Library Online (Scielo), with national and international publications, carried out from 2007 to 2017 through the following descriptors: Sickle Cell Anemia, Profile, Children. Results: The results revealed that brown-skinned 2 to 8year-old children with the SS type genotype were the most frequently mentioned with sickle cell anemia (SCA). Among the clinical manifestations of SCA, they indicated: the infection; acute splenic sequestration; behavioral and performance problems of social competence, pain, skin paleness, fever, weight and iron deficiency, short stature and problems prosthetics. Final considerations: It is concluded that early diagnosis and specific interventions will allow, in addition to reducing physical damage, the adoption of more proactive strategies in view of the limitations imposed by the disease.
\end{abstract}

Key words: Anemia, Sickle cell, Health profile, Child.

\section{RESUMO}

Objetivo: O objetivo deste estudo é analisar o perfil clínico epidemiológico de crianças com anemia falciforme, publicados na literatura nos últimos dez anos. Métodos: Trata-se de uma revisão integrativa. Para a busca dos artigos, utilizou-se a Biblioteca Virtual em Saúde (BVS), e os artigos do banco de dados da Literatura Científica e Técnica da América Latina e do Caribe (LILACS) da base de dados Medical Literature Analysis and Retrieval System Online (MEDLINE) foram selecionados, dados da Scientific Electronic Library Online (Scielo), com publicações nacionais e internacionais, realizados de 2007 a 2017, através dos seguintes descritores: Anemia Falciforme, Perfil, Crianças. Resultados: Os resultados revelaram que crianças de 2 a 8 anos de idade, de pele parda, com o genótipo tipo SS foram as mais citadas com anemia falciforme (AF). Entre as manifestações clínicas da AF, indicaram: a infecção; sequestro esplênico agudo; problemas comportamentais e de desempenho de competência social, dor, palidez da pele, febre, deficiência de peso e ferro, baixa estatura e problemas protéticos. Considerações finais: Conclui-se que o diagnóstico precoce e intervenções específicas permitirão, além de reduzir os danos físicos, a adoção de estratégias mais proativas diante das limitações impostas pela doença.

Palavras-chave: Anemia, Células falciforme, Perfil de saúde, Criança.

\footnotetext{
${ }^{1}$ Federal University of Maranhão (UFMA), São Luís - MA. *E-mail: joabearaujobiotec@gmail.com

${ }^{2}$ Federal University of Maranhão (UFMA), Grajaú - MA.

${ }^{3}$ State University of Maranhão (UEMA), Colinas - MA.

${ }^{4}$ State University of Maranhão (UEMA), Bacabal - MA.
} 


\section{RESUMEN}

Objetivo: El objetivo de este estudio es analizar el perfil clínico epidemiológico de niños con anemia falciforme, publicado en la literatura en los últimos diez años. Métodos: Es una revisión integradora. Para buscar los artículos, utilizamos la Biblioteca Virtual en Salud (BVS) y artículos de la base de datos de Literatura Científica y Técnica de América Latina y el Caribe (LILACS) de la base de datos en línea del Medical Literature Analysis and Retrieval System Online (MEDLINE) fueron seleccionados, datos de la Biblioteca Electrónica Científica en línea (Scielo), con publicaciones nacionales y estudios internacionales, realizados entre 2007 y 2017, a través de los siguientes descriptores: anemia falciforme, perfil, niños. Resultados: Los resultados revelaron que los niños de piel morena de 2 a 8 años con genotipo tipo SS fueron los más frecuentemente mencionados con anemia falciforme (SCA). Entre las manifestaciones clínicas de SCA, indicaron: la infección; secuestro esplénico agudo; problemas de comportamiento y comportamiento social, dolor, palidez de la piel, fiebre, deficiencia de peso y hierro, baja estatura y problemas protésicos. Consideraciones finales: Se concluye que el diagnóstico temprano y las intervenciones específicas permitirán, además de reducir el daño físico, la adopción de estrategias más proactivas en vista de las limitaciones impuestas por la enfermedad.

Palabras clave: Anemia, Células falciformes, Perfil de salud, Niño.

\section{INTRODUCTION}

Sickle cell anemia or drepanocitica-HB SS (Homozygoetic) was first described in 1910 by James Herrick, which studied diseases related to the presence in the blood of sickle cell and since then this disease has presented itself as a major impact on public health worldwide. This disease originated in Africa, arriving in Brazil by forced immigration of Africans due to miscegenation, favoring its dispersion (BRAGA JA, et al., 2014).

This disease has 4 types of clinical diagnoses, two with alpha chain and two with beta chain. Hemoglobin $\mathrm{SS}$ is the most common type of case, characterized by the fact that individuals inherit copies of the hemoglobin $\mathrm{S}$ gene from both parents, leading to the creation of a hemoglobin Hb SS. This is also responsible for generating the worst clinical symptoms for patients. Hemoglobin SC is the second most common case of sickle cell anemia, affecting individuals who inherit the $\mathrm{Hb} C$ gene from one parent and the $\mathrm{Hb} \mathrm{S}$ gene from the other. The symptoms are similar to those presented by $\mathrm{Hb} \mathrm{SS}$, however, the condition is less severe. (BARBERINO IA, et al., 2019).

Hemoglobin $\mathrm{Sb}+$ (Beta) Thalassemia impairs the production of beta globin genes by affecting the size of red blood cells that are reduced because fewer beta proteins are produced. Beta-Zero Thalassemia, on the other hand, has symptoms similar to $\mathrm{Hb}$ SS anemia. Sometimes the symptoms of beta-zero thalassemia are more severe and are associated with a worse prognosis (CASTRO IPS e VIANA MB, 2019).

According to estimates by the World Health Organization (WHO), $5 \%$ of the world's population carries the gene for hemoglobinopathies and each year approximately 300,000 children with this disease are born (WHO, 2006). In Brazil, sickle cell anemia is the most common hereditary monogenic disease, occurring predominantly among people of African descent. Currently, it is estimated that there are 20 to 30 thousand Brazilians with this disease and that requires public health measures. Sickle cell disease has a heterogeneous spatial distribution, being more frequent in the North and Northeast states (BRAZIL, 2012).

Sickle cell anemia is a disease of a genetic nature, the result of a mutation in which the glutamic amino acid alternates with the valine in hemoglobin beta chain codon 6 , resulting in the formation of hemoglobin S. This failure is primarily responsible for the variety of clinical manifestations of the disease (MENESES JVL et al., 2010). According to data from the Department of Informatics of the Unified Health System (DATASUS, 2009) in relation to childhood aggravation rates, the incidence of sickle cell disease is higher than that of diseases such as Dengue and Acquired Immunodeficiency Syndrome (AIDS) in children under 5 years.

Patients with sickle cell anemia are extremely vulnerable to infections mainly of the respiratory tract, and the encapsulated germs are the most responsible. Infectious processes are the main cause of children's morbidity and mortality. They are more frequent and severe in those under five years of age. They may initially 
manifest with fever and lead to the child's death within 12 hours. The risk of pneumococcal meningitis is estimated to be 600 times higher than in the general population and the frequency of bacteremia up to 300 times higher than expected for age, with $90 \%$ of cases occurring in the first three years of life (MORAIS MB, et al., 2013).

Because it is a chronic disease and healing through bone marrow transplantation is a reality somewhat distant from most, the prevention of sickle cell anemia is only possible by incorporating information on reproductive risk. The priority strategy is to identify and inform people at risk early, that is, before they start their reproductive projects, in order to inform them of the likelihood of having future children with this disease. However, an option for reproductive genetic counseling widespread in Brazil is in the neonatal phase, ie immediately after the birth of a child with sickle cell disease in order to guide future pregnancies (FERNANDES APPC, et al., 2010).

In this perspective, the foot test not only detects sickle cell anemia, but also screens sickle cell disease patients. Sickle cell anemia has no specific treatment, but prophylactic measures decrease the severity of the clinical picture as well as the mortality due to it. Thinking about the importance of performing the foot test, the Ministry of Health, by ministerial order n. 822 of June 2001, made neonatal screening for hemoglobin S (Hb S) compulsory throughout Brazil free of charge and linked to a comprehensive care program for diagnosed people. This examination also enables the identification of phenylketonuria and congenital hypothyroidism (BRAZIL, 2012).

It is important to mention that the newborn with sickle cell anemia is usually asymptomatic due to the protective effect of fetal hemoglobin, which in this period of life represents approximately $80 \%$ of total hemoglobin. Therefore, sickling tests (drepanocyte research) and solubility tests do not apply during the first months of life. False positive results are acceptable as long as all positive or suspected cases are retested by another method. Thus, the importance of using two different techniques to determine the hemoglobin profile in the first screening sample (BRAGA JA, et al., 2014).

Given the above, it is understood that the drop in mortality and the improvement in the quality of life of sickle cell disease patients are directly proportional to the access and care provided in the public network, especially the state (BRAGA JA, et al., 2014). However, of the 27 Brazilian states, according to Brazil (2009), only 18 perform neonatal screening for sickle cell disease and, consequently, their monitoring in specialized centers. Therefore, it is extremely important to know, analyze and disclose all aspects that involve the clinical epidemiological profile of children with sickle cell anemia, so that they can follow up the processes of implementation of the National Program for Integral Attention to People with Sickle Cell Disease throughout the national territory.

Thus, it is important that health professionals recognize sickle cell anemia as an important cause of morbidity in today's society, because its incidence is high and represents an important aggravating factor in the prognosis of these individuals. Therefore, it is justified the proposal to research on sickle cell anemia and to analyze factors that evidence peculiar characteristics published in research in several Brazilian states and municipalities and also internationally. Thus, this study aimed to analyze the clinical epidemiological profile of children with sickle cell anemia, published in the literature in the last ten years.

\section{METHODS}

Considering the proposed objective, an integrative review research was chosen, using as a reference the method adopted by Souza MT et al. (2010), with some modifications. The following databases were used to survey this research: Virtual Health Library (VHL), and articles from the Latin American and Caribbean Scientific and Technical Literature (LILACS) and Medical Literature Analysis and Retrieval System Online database were selected (MEDLINE) and also from the Scientific Electronic Library Online (Scielo) database, with national and international publications, carried out from 2007 to 2017 through the following descriptors: Sickle Cell Anemia, Profile, Children, which were combined with the word "And". The criteria adopted for the selection of articles were: articles indexed in national and international journals that portrayed the theme regarding the integrative review. 


\section{RESULTS}

Table 1 - presents the distribution of authors, year of publication, journal and database of the 11 studies evaluated. Determination of authorship, year of publication, journal and database by bibliographic survey between 2007 and 2017.

\begin{tabular}{|c|c|c|c|c|}
\hline $\mathbf{N}$ & Authors & $\begin{array}{c}\text { Year of } \\
\text { publication }\end{array}$ & Periodical & database \\
\hline 1 & Boulet SL et al. & 2010 & Am. Prev. Med. & MEDLINE \\
\hline 2 & Fernandes APPC et al. & 2010 & Jornal de Pediatria & MEDLINE \\
\hline 3 & $\begin{array}{l}\text { Lorencini GRF e Paula } \\
\text { KMP }\end{array}$ & 2015 & Temas Pscol. & Scielo \\
\hline 4 & Len CA et al. & 2013 & Rev. Paul Pediatri. & Scielo \\
\hline 5 & Nogueira ZD et al. & 2015 & Rev. Paul Pediatri. & Scielo \\
\hline 6 & Palermo TM et al. & 2008 & J. Pain. & LILACS \\
\hline 7 & Pinho L et al. & 2012 & Rev. Baiana Saúde Pública & LILACS \\
\hline 8 & Rodrigues PC et al. & 2011 & Jornal de Pediatria & MEDLINE \\
\hline 9 & Santos PND et al. & 2014 & Cogitare Enferm. & LILACS \\
\hline 10 & Souza KCM et al. & 2011 & Rev. de Nutrição & Scielo \\
\hline 11 & Watanabe AM et al. & 2008 & Cad. Saúde Pública & Scielo \\
\hline
\end{tabular}

Source: Carvalho GC, et al., 2019.

It was observed that the year with the largest number of publications was 2010 and the year 2015 with two publications. Although the selected period comprised research from 2007 to 2017 , no articles were identified in the years 2007 and 2009. The most prominent journal was Jornal de Pediatria and Revista Paulista de Pediatria each with two articles. 
Table 2 - presents the sociodemographic profile (age, sex and race) found in the 11 researches evaluated. Determination of the sociodemographic profile of the patients, through bibliographic survey, from 2007 to 2017.

\begin{tabular}{ccc}
\hline Variables & No of research & $\%$ \\
\hline Age range (years) & 03 & 27,27 \\
0 to 1 year and 11 months & 04 & 36,36 \\
2 to 6 & 03 & 27,27 \\
8 to 12 & 01 & 9,09 \\
Greater than 12 years & & \\
Sex & 07 & 63,63 \\
Feminine & 04 & 36,36 \\
Male & & \\
Race & & 18,18 \\
White & 02 & 54,54 \\
Brown & -- \\
Yellow & 06 & 18,18 \\
Black & -- & 9,09 \\
Not mentioned & 02 & $\mathbf{1 0 0}$ \\
TOTAL & 01 & \\
\hline
\end{tabular}

Source: Carvalho GC, et al., 2019.

It was possible to identify that the most prevalent age group was 2 to 6 years old with $3(27.27 \%)$ articles, and $7(63.63 \%)$ indicated the female gender as the most evidenced and $6(54,54 \%)$ showed the brown as color most prevalent among the researchers evaluated.

Graph 1 represents the clinical form of sickle cell anemia, where 10 articles (68.33\%) presented SS or SC and only one article (31.67\%) presented Sbeta.

Graph 1 - Clinical Forms of Sickle Cell Anemia in children demonstrated in the evaluated articles, Teresina-PI

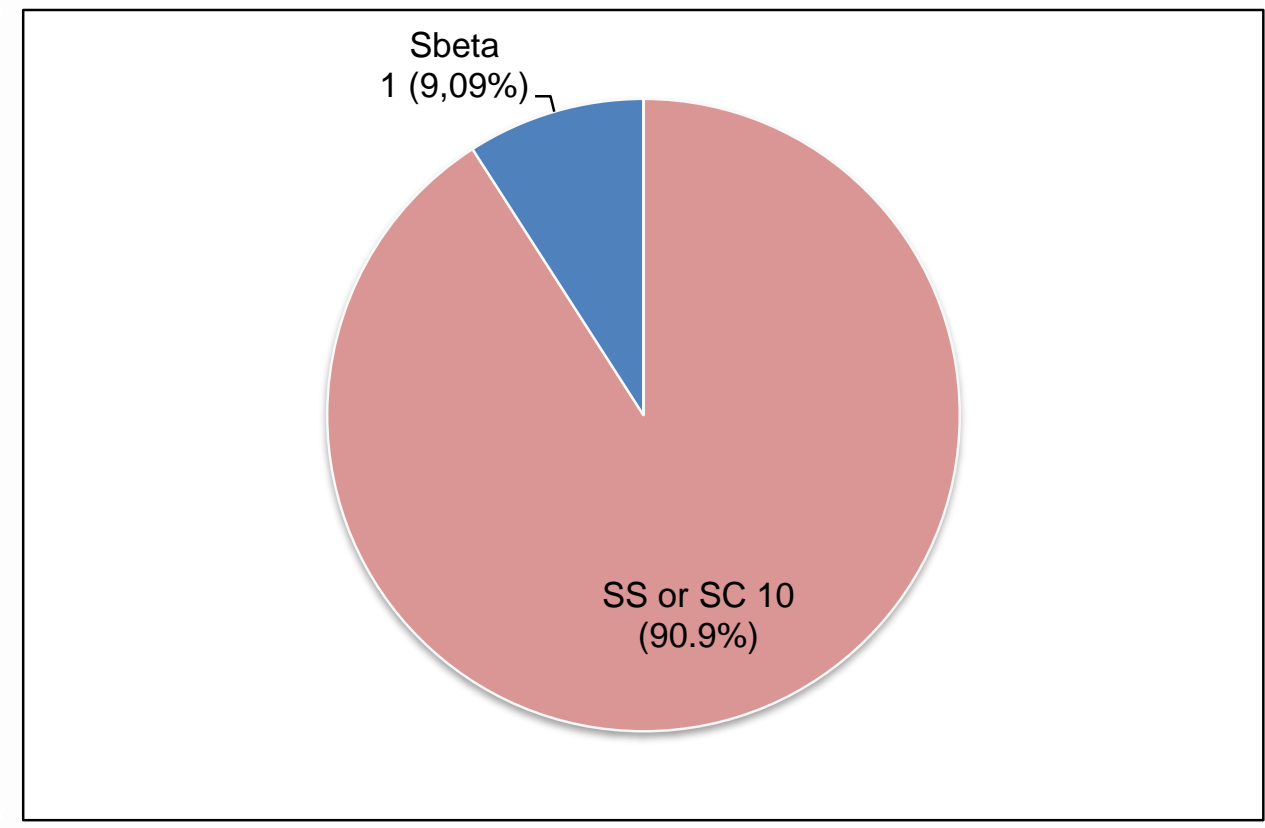

Source: Carvalho GC, et at., 2019 
Regarding the clinical presentation of sickle cell anemia, the results of this research showed that the articles identified the clinical form Sbeta as the least prevalent with only $1.1 \%$ and the form SS $90.9 \%$ as the most prevalent.

Table 3 - presents the authorship studies on the clinical manifestations of sickle cell anemia presented in the last 10 years, as well as its prognoses. Determination of authorship, year and clinical manifestations presented in articles published between 2007 and 2017.

\begin{tabular}{|c|c|}
\hline Authors/year & Clinical manifestations \\
\hline Boulet SL, et al. (2010) & $\begin{array}{c}\text { Frequent headaches or migraines, intellectual disabilities, and } \\
\text { regular medication use. }\end{array}$ \\
\hline Fernandes APPC, et al. (2010) & $\begin{array}{l}\text { High number of deaths, where the causes were: } 38.5 \% \\
\text { infection; } 16.6 \% \text { acute splenic sequestration; } 9 \% \text { other causes. }\end{array}$ \\
\hline Lorencini GRF e Paula KMP (2015) & Behavior problems for the performance of a social competence. \\
\hline Len CA, et al. (2013) & Pain that impacted Health-Related Quality of Life (HRQoL). \\
\hline Nogueira ZD, et al. (2015) & Somatic complaints, hyperactivity and social withdrawal. \\
\hline Palermo TM, et al. (2008) & $\begin{array}{l}\text { Skin pallor, fever, pain crisis, Somatic complaints, hyperactivity } \\
\text { and social withdrawal. }\end{array}$ \\
\hline Pinho L, et al. (2012) & $\begin{array}{l}\text { High frequency of hospitalization and complications (fever, } \\
\text { painful crises, infections), insufficient energy, protein and } \\
\text { micronutrient intake and increased basal metabolic rate. }\end{array}$ \\
\hline Rodrigues PC, et al. (2011) & Weight and iron deficit. \\
\hline Santos PND, et al. (2014) & Pallor, fever and pain crisis. \\
\hline Souza KCM, et al. (2011) & Short stature and prosthetic problems. \\
\hline Watanabe AM, et al. (2008) & Short stature and prosthetic problems. \\
\hline
\end{tabular}

Source: Carvalho GC, et al., 2019.

\section{DISCUSSION}

\section{Clinical and Epidemiological Profile of Children with Sickle Cell Anemia (SCA) Evidenced in research}

Nogueira ZD, et al. (2015) conducted a survey of 357 children aged 2 to 6 years, and found that $52.9 \%$ were boys, $52.9 \%$ had a mean age of 3.7 years, $80 \%$ had hemoglobin SS and $67 \%$ were brown in color. Lorencini GRF and Paula KMP (2015) identified the same results regarding gender, race and clinical form, but in another age group from 8 to 10. Pinho L, et al. (2012) identified the different gender, as most were girls, aged 2 to 6 years and brought other epidemiological characteristics, as more than $90 \%$ of the children had age-appropriate height and weight, and the nutritional status prevailed over the others. Although predominantly eutrophic, the children with SCA evaluated had some important dietary deficits, especially regarding micronutrients (folic acid, vitamin $\mathrm{D}$ and vitamin B12). In Rio de Janeiro, 161 children between 2 and 6 years old were evaluated, being $50.3 \%$ male $(n=81)$ and $49.7 \%$ female $(n=80)$. The skin color variable was only available for 38 children ( 4 white, 8 black and 26 brown). In addition, it was observed that $27 \%$ lived in families with more than 5 people, $54.2 \%$ had 4 or more rooms in the residence, $95.7 \%$ were served by the general water supply and $87.2 \%$ through the sewer network. It was also possible to identify different results in relation to anthropometric data, as $76 \%$ of the evaluated children had short stature (SOUZA KCM, et al., 2011).

Boulet SL, et al. (2010) compared 192 children aged 8 to 12 years with SCA whose race was reported as black or African-American, and 19,335 children without SCA of the same age and race, most of whom were 
girls. It was possible to identify that black children with SCA were more likely to have frequent headaches or migraines, intellectual disabilities, regular medication use, and fair or poor health compared to black children without SCA. Watanabe AM, et al. (2008) conducted their research in the state of Paraná, with 548,810 newborns, who underwent the "foot test", from 2002 to 2004 . It was possible to identify 24 children with the diagnosis of SCA, where most were girls, from 0 to 6 months of age, white in color and with higher prevalence of the form $S \beta$-talassemia.

Another study in the state of Paraná showed that the age group was 8 to 12 years old, mostly girls brown, $82 \%$ with $\mathrm{Hb}$ S genotype, $66.7 \%$ lived in brick houses; $87.8 \%$ had basic sanitation; $80 \%$ were diagnosed before the first year of life and $86.2 \%$ were periodically followed for three years or more at the state outpatient clinic (SANTOS PND, et al., 2014). In the state of Minas Gerais, Fernandes APPC, et al. (2010) also used the results of the "foot test", where 1,833,030 children were screened from 2005 to $2010,1,396$ with sickle cell disease (1: 1,300$)$. It was identified that $54 \%$ were aged 0 to 6 months, $65 \%$ were girls, $76 \%$ were brown and $67 \%$ had the SS genotype. The number of deaths among children diagnosed with SCA was 56 (71.8\%), who died before 2 years of age. Also in Minas Gerais, Rodrigues PC, et al. (2011) evaluated 135 infants, $90 \%$ under 2 years old (66 boys and 69 girls), with SS and SC genotypes (77/58) respectively and 68\% brown. In addition, most children with sickle cell disease were born, with adequate weight for gestational age, and $17.8 \%$ of children had iron deficiency. Palermo TM, et al. (2008) conducted a survey in Clevelan-USA with 224 children with SCA, where the most prevalent age group was 8 to 12 years old, 57\% male, brown and with the Hb S genotype.

Len CA, et al. (2013) conducted their research with 100 children with SCA in São Paulo, divided into three subgroups according to age group: from 5 to $7(n=18)$, from 8 to $12(n=32)$ and from 13 to 18 years $(n=50)$ and with their respective parents. The Control Group was composed of 50 healthy children and adolescents from a local public school, also divided into the three subgroups by age and their respective parents. It was possible to identify that most were girls, black and had the form $\mathrm{Hb} \mathrm{S}$.

\section{Clinical Changes of Children with Sickle Cell Anemia (SCA)}

As clinical signs, Santos PND, et al. (2014) identified with cutaneous pallor (94.8\%) and fever (93.1\%), and the main complication was pain crisis $(70.7 \%)$. This latter manifestation is caused by microvascular occlusion with subsequent tissue injury in response to red blood cells. Palermo TM, et al. (2008) also identified the same clinical changes, but in slightly different percentages. Boulet SL et al. (2010) demonstrated that children with SCA had frequent headaches or migraines, intellectual disabilities, and regular medication use. Pain was also the main clinical manifestation mentioned in the research by Len CA, et al. (2013), which impacted on the Health-Related Quality of Life (HRQoL) of patients with SCA and their families, although its intensity varies and depends on the individual characteristics of each patient, family and cultural contexts, as well as of the multiprofessional team responsible for the assistance.

Children with this disease had impaired quality of life and their respective families. Patients perceive emotional, social, family and physical restrictions. According to Len CA, et al. (2013) the negative repercussion on the domains and mental component may be due to caregivers' excessive concern with the patient's health, the difficulty in dealing with the manifestations of the disease and the possible changes in family routine imposed by medical treatment and frequent hospital procedures.

Rodrigues PC, et al. (2011) demonstrated other clinical aspects, as they presented weight deficit, but not height, when compared to the standard population and also iron deficiency. No significant differences in anthropometric indices were observed when the groups were separated according to hemoglobinopathy (SS versus SC). Lorencini GRF and Paula KMP (2015) identified that sickle cell anemia is a risk factor for the occurrence of behavioral problems and the performance of adequate social competence, which may be related to restrictions in the exercise of activities common to other children, which limits the frequency and quality of peer interaction. Possibly, the restrictions imposed by the disease affected the willingness to play or be alone, especially in the school context, which may lead to anxiety and depression. For Nogueira ZD, et al. (2015) Somatic complaints, hyperactivity and social withdrawal can be seen as coping mechanisms that lead to states of depression and anxiety. For the authors, behavioral problems in this population can be interpreted as representing the use of inefficient coping techniques in face of the stressor of the disease.

REAS/EJCH | Vol.12(2) | e2774 | DOI: https://doi.org/10.25248/reas.e2774.2020 Página 7 de 9 
Palermo TM, et al. (2008) also identified results similar to the previous ones, since multivariate regression analysis revealed that individual and family socioeconomic distress was a significant predictor of functional disability and physical and psychosocial HRQoL in the evaluated children. Pinho L, et al. (2012) pointed out in their results other changes resulting from SCA, such as: high frequency of hospitalization and complications (fever, painful crises, infections), insufficient consumption of energy, protein and micronutrients and increased basal metabolic rate. The increase in the basal metabolic rate of patients with SCA is due, among other factors, to the increased erythropoiesis rate and cardiac work due to chronic anemia. Souza KCM, et al. (2011) and Watanabe AM, et al. (2008) pointed to short stature and dietary problems in children evaluated with SCA. In another research it was possible to identify a high number of deaths in the evaluated children, where the causes were: $38.5 \%$ infection; $16.6 \%$ acute splenic sequestration; $9 \%$ other causes; $15.4 \%$ without medical assistance; and $20.5 \%$ undetermined (FERNANDES APPC, et al., 2010).

\section{Strategies for Coping with Sickle Cell Anemia (SCA) in Children}

Lorencini GRF and Paula KMP (2015) highlight the importance of a positive adaptation to the disease, considering early diagnosis and treatment adherence as protective factors for development in the SCA population. Pinho L, et al. (2012) also agree with previous authors and add that early diagnosis and specific interventions will allow, in addition to reducing physical damage, the adoption of more proactive strategies in the face of stressors, reducing the pattern of anxiety and depression. Some studies agree that there is a need to invest in more outpatient assessment and intervention programs that broaden the repertoire of cognitive skills and coping strategies, qualifying both parents and children to cope with adverse situations arising from the clinical manifestations of sickle cell anemia (FERNANDES APPC, et al., 2010; NOGUEIRA ZD, et al., 2015; SOUZA KCM, et al., 2011). According to Fernandes APPC, et al. (2010) the problem of sickle cell disease is not only limited to technical issues, but is also a political and social issue, which should involve patients, families and professionals in order to improve their current life and health conditions.

Pinho L, et al. (2012) mention the importance of differentiated nutritional care for patients with SCA as essential to improve disease prognosis and quality of life. The nutritional approach of SCA requires qualification and training of professionals who provide primary health care, especially considering the limitation of families to understand the need for treatment, adhere to the proposed diet and purchase different food items. Souza KCM, et al. (2011) also agree with the previous thinking and add that socioeconomic and demographic factors need to be better known by health services, in order to allow proper characterization of this aspect in the clientele served. In addition, knowing the evolutionary periods of SCA allows health professionals to establish more accurate care behaviors, since due to the severity of the hemolytic process, there are early deficits in weight and height, as well as delays in sexual maturation, children and teenagers.

Palermo TM, et al. (2008) refer to the importance of family education, offered through medical care and also by the multiprofessional team (nurses, psychologists, nutritionists and others). Such guidelines are seen as key resources for those at risk. Boulet SL, et al. (2010) agree with the above thinking and draw attention to their findings that the health burden for children with sickle cell disease and their families is profound and may be exacerbated by barriers to accessing comprehensive medical care and ineffective treatments for clinical manifestations.

According to Len CA, et al. (2013) the act of caring demands attention overload and intensive care and, as the family is the main executor of this role, it is of great importance that the health team ensures conditions for parents to restructure physically and emotionally in face of this new phase of care, responsibilities. Caregivers are the main allies of health professionals in the treatment of patients. It is necessary that health professionals have a global view of patients and caregivers, so that they promote strategies with the potential to improve well-being and health conditions.

Some research suggests that an individualized assessment should be performed, given the impact of iron deficiency anemia on somatic and cognitive development and the lack of evidence that contraindicates iron supplementation in infants with sickle cell disease. Iron kinetics tests are useful in doubtful cases and should be interpreted based on clinical and hematological data (RODRIGUES PC, et al., 2011; SANTOS PND, et al., 2014; WATANABE AM, et al., 2008). 


\section{FINAL CONSIDERATIONS}

From the results presented in this study, it can be concluded that the women, from 2 to 8 years old, brown color and SS type genotype were the most cited with ACS. Emphasizing the need for strategies to cope with ACS in children and the need for trained professionals to meet the peculiarities of children and their families individually, always seeking to adhere to family and patient to medical recommendations. Thus, the lack of findings in the literature on psychosocial aspects of individuals with ACS is limited to few scientific studies on the subject. This reinforces the need for further studies to help professionals in health care networks. Finally, early diagnosis and specific interventions will allow, besides reducing physical damage, the adoption of more proactive strategies in view of the limitations imposed by the disease.

\section{REFERENCES}

1. BARBERINO IA, et al. Autoimagem e estigma social na doença falciforme: uma revisão integrativa. Revista Eletrônica Acervo Saúde, 2019; 11(8):e530-e530.

2. BOULET SL, et al. Health Status and Healthcare Use in a National Sample of Children with. Am. J. Prev. Med, 2010; 38(4):S528-S535.

3. BRAGA JA, et al. Doença falciforme. Hematologia e Hemoterapia Pediátrica. São Paulo: Atheneu, 2014:139-162.

4. Brazil. Ministério da Saúde. Secretaria de Atenção à Saúde. Departamento de Atenção Especializada. Manual de eventos agudos em doença falciforme/Ministério da Saúde, Secretaria de Atenção à Saúde, Departamento de Atenção Especializada. - Brasília: Editora do Ministério da Saúde, 2009.

5. Brazil. Ministério da Saúde. Secretaria de Atenção à Saúde. Departamento de Atenção Especializada. Doença falciforme: condutas básicas para tratamento/Ministério da Saúde, Secretaria de Atenção à Saúde, Departamento de Atenção Especializada. Brasília : Ministério da Saúde, 2012.

6. CASTRO IPS, VIANA MB. Cognitive profile of children with sickle cell anemia compared to healthy controls. Jornal de pediatria, 2019; 95(4):451-457.

7. CERVO AL, BERVIAN PA. Metodologia Científica. 5 ed. São Paulo: Prentice Hall. 2006; 137p.

8. DATASUS. 2009. Departamento de Informática do SUS. Brasília: Ministério da Saúde. Disponível em: http://www.datasus.gov.br/. Acesso em: 14 set. 2019.

9. FERNANDES APPC, et al. Mortality of children with sickle cell disease: a population study. Jornal de pediatria, 2010; 86(4):279-284.

10. LEN CA, et al. Qualidade de vida em portadores de doença falciforme. Revista Paulista de Pediatria, 2013; 31(1):2429.

11. LORENCINI GRF, PAULA KMP. Perfil comportamental de crianças com anemia falciforme. Temas psicol., Ribeirão Preto, 2015; 23(2):269-280.

12. MENESES JVL, et al. Úlceras maleolares em portadores de anemia falciforme: manejo clínico e operatório. Gazeta Médica da Bahia, 2010; 80(3):89-94.

13. MORAIS MB, et al. Pediatria - Diagnostico e Tratamento. 1르 ed. Barueri: Editora Manole, 2013, 2144p.

14. NOGUEIRA ZD, et al. Breastfeeding and the anthropometric profile of children with sickle cell anemia receiving followup in a newborn screening reference service. Rev Paul Pediatr, 2015; 33(2):154-159.

15. PALERMO TM, et al. Daily functioning and quality of life in children with sickle cell disease pain: relationship with family and neighborhood socioeconomic distress. The Journal of pain, 2008; 9(9):833-840.

16. PINHO L, et al. Perfil antropométrico e dietético de crianças com anemia falciforme. Rev. Baiana de Saúde Pública, 2013; 36(4):935-950.

17. RODRIGUES PC, et al. Deficiência de ferro em lactentes brasileiros com doença falciforme. J. pediatr, 2011; 87(5):405-411.

18. SANTOS PND, et al. Anemia falciforme: caracterização dos pacientes atendidos em um ambulatório de referência. Cogitare Enfermagem, 2014; 19(4):785-793.

19. SOUZA KCM, et al. Baixa estatura e magreza em crianças e adolescentes com doença falciforme. Rev Nutr, 2011; 24(6):853-862.SOUZA MT, et al. Revisão integrativa: o que é e como fazer. Einstein (São Paulo), 2010; 8(1):102-106.

20. WATANABE AM, et al. Prevalência da hemoglobina S no Estado do Paraná, Brasil, obtida pela triagem neonatal. Cad Saúde Pública, 2008; 24:993-1000.

21. World Health Organization (2006). Sickle-cell anaemia: report by the Secretariat. Executive Board, 117. available from: https://apps.who.int/iris/handle/10665/20659 